Article

\title{
Foreign Ownership and Corporate Social Responsibility: Evidence from China
}

\author{
Mingyuan Guo * and Chendi Zheng
}

check for

updates

Citation: Guo, M.; Zheng, C. Foreign Ownership and Corporate Social Responsibility: Evidence from China. Sustainability 2021, 13, 508. https:// doi.org/10.3390/su13020508

Received: 10 December 2020

Accepted: 1 January 2021

Published: 7 January 2021

Publisher's Note: MDPI stays neutral with regard to jurisdictional clai$\mathrm{ms}$ in published maps and institutional affiliations.

Copyright: $(\odot 2021$ by the authors. Licensee MDPI, Basel, Switzerland. This article is an open access article distributed under the terms and conditions of the Creative Commons Attribution (CC BY) license (https:// creativecommons.org/licenses/by/ $4.0 /)$.
College of Management and Economics, Tianjin University, Tianjin 300072,China; di_818@tju.edu.cn

* Correspondence: guomingyuan@tju.edu.cn

\begin{abstract}
This paper employs the data of corporate social responsibility rating score of A-share listed companies in China from 2009 to 2018 as a sample to verify the impacts of foreign ownership on corporate social responsibility. Furthermore, this paper explores the moderating role of legal institutional distance and economic institutional distance in the impact of foreign ownership on corporate social responsibility. The empirical results of panel data models show that: Firstly, foreign ownership has a significant positive impact on corporate social responsibility. Secondly, legal institutional distance and economic institutional distance have a positive moderating role in the impacts of foreign ownership on corporate social responsibility. The results of propensity score matching, two-stage least squares and alternative variables methods also give strong backing to the above conclusions. Finally, this paper puts forward that China's listed companies are supposed to make full use of the supervision power of foreign ownership to promote corporate social responsibility.
\end{abstract}

Keywords: foreign ownership; corporate social responsibility; legal institutional distance; economic institutional distance; panel data model; China

\section{Introduction}

The traditional profit maximization goal of companies leads to a whole string of social problems, such as employee rights and interests, food safety and quality and environmental pollution, which impede the healthy pullulating of companies. This makes companies face increasing pressure from different stakeholders, forcing listed companies to integrate sustainable strategies in their operations. Since the 1920s, corporate social responsibility (CSR) has stolen more limelight from stakeholders. CSR requires companies to show solicitude for the interests of other stakeholders while pursuing economic interests and creating shareholder wealth. CSR is actually the top priority of modern enterprises (Menguc and Ozanne [1]). Under the well-established Triple Bottom Line (TBL) accounting framework, companies are required to solve economic, ecological and social sustainability problems in varying degrees (Peloza and Shang [2]). The stratospheric growth of CSR is not only a mandatory approach, but also a voluntary approach taken by companies for their own interests. CSR can enhance corporate reputation and improve corporate financial performance synchronously. CSR is increasingly becoming a worldwide phenomenon. In this regard, developed countries have launched campaigns and issued corresponding laws and regulations to promote the implementation of CSR. Moreover, international organizations have also issued SA8000, the United Nations Global Compact, ISO26000 and other standards. This indicates that the implementation of CSR has become the consensus of the international community. At present, CSR remains the focus of the world of business. In 2019, the chief executive officers of 181 top American companies jointly signed "The Declaration of Corporate Purpose", which redefined the pursuit of the company's operation to remodel a better society, instead of on the traditional profit maximization goal. In the same year, the "European Green Agreement" announced by European Commission also covers almost all areas and aims at adopting carbon neutral measures, such as reducing 
carbon emissions, restoring biodiversity and improving resource utilization to elevate the development of European Union.

With China's remarkable economic growth, Chinese companies are occupying an increasingly significant position in the global market. People's attention to CSR has gradually arrived to China, and China's exploration of CSR has also correspondingly blossomed. China's CSR practice started late, but in the past decade, it has been fully supported and developed. In 2006, the Shenzhen Stock Exchange (SZSE) issued the "Guidelines on Social Responsibility of Listed Companies" (More details about the "Guidelines on Social Responsibility of Listed Companies" can be retrieved from the website: http:/ / www.csrc.gov.cn/ pub/shenzhen/xxfw/tzzsyd/ssgs/sszl/ssgsfz/200902/t20090226_95495.htm. Accessed 15 January 2020) to guide listed companies to actively perform their CSR. Subsequently, the "Guidelines on the Application of Internal control of Enterprises" (More details about the "Guidelines on the Application of Internal control of Enterprises" can be retrieved from the website: http:/ / www.csrc.gov.cn/pub/fujian/xxfw/fjssgsnk/201204/t20120 411_208407.htm. Accessed 15 January 2020) and "China Corporate Law" (More details about the "China Corporate Law" can be retrieved from the website: http:/ / www.csrc.gov. cn/shanxidong/xxfw/tzzsyd/200511/t20051114_92273.htm. Accessed 15 January 2020) also precisely stipulate that companies are supposed to energetically fulfill their CSR. The 18th and 19th National Congress of the Communist Party of China also raised CSR to a strategic level. The "2018 China Corporate Social Responsibility Report" (More details about the "2018 China Corporate Social Responsibility Report" can be retrieved from the website: http:/ / www.xinhuanet.com/tech/2018-12/28/c_1123919630.htm. Accessed 15 January 2020) points out that, although the number and disclosure of China's CSR reports are constantly elevating, the overall level of CSR is still low and in the primary stage. In addition, under many regulations and moral constraints, there have still been incidents of neglecting social responsibility in recent years, such as the "aromatic hydrocarbon" incident of infant milk powder, the "sweet element" incident of Jiugui Liquor, the "expired vaccine" incident in Jinhu, the "carbon nine leakage" incident in Fujian, the third phase of female employees' rights and interests damage, etc. However, Sustainable development of enterprises and CSR are not separated and antagonistic, but coordinate and promote each other. They are unified in the development process of enterprises and society (Wang and Han [3]; Qu et al. [4]; Hristov et al. [5]). The performance of CSR has increasingly proved to be the constraints of the long-term development of companies. Under the background of the "new normal" macro-economy, better CSR performance can provide leading advantages, innovative ways and resource bases for the sustainable development of enterprises, promote the improvement of enterprises' sustainable development ability and carry out the sustainable development of the whole society (Song et al. [6]). Therefore, how to improve CSR has gradually become the focus of scholars.

With the penetrating enforcement of the reform and opening-up policies and the expediting of the process of globalization, China's capital market has been further opened. A mass of foreign investors is investing in Chinese companies. Foreign owners often hold shares in Chinese listed companies through different forms and motivations. Foreign ownership performs an increasingly significant role in corporate governance. Therefore, the CSR performance of companies with foreign ownership is a topic of interest. The increase of foreign ownership has opened up new potential channels for companies to fulfill their CSR. With the processive strengthening of global economic communications, the institutional distances among countries will also affect the flow of information and capital in different countries, thus affecting the strategic decision-making and value of companies. It is worth further exploring the role of institutional distances. With the rise of the concept of sustainable development investment, CSR has gradually become the focus of investors. Therefore, how to use foreign capital to achieve better implementation mechanism of CSR and how to carry out CSR activities according to the characteristics and attributes of foreign investors are of great significance to the sustainable development of enterprises and society (Wang and Lee [7]). 
At present, many scholars have demonstrated that the different ownership structures of companies have different impacts on the disclosure of CSR performance (Li [8]; Sun, and Tao [9]; Gloßner [10]). With the increasing process of global integration, on the basis of the research pertaining to ownership structure and CSR, some scholars deeply study the influencing mechanisms of foreign investment on CSR, but the breadth and depth of the research have thus far been extremely lacking. Most of the existing research investigates the impact of foreign direct investment (FDI) on CSR from a macroscopic perspective (Lin and Lou [11]; Huang and Chen [12]; Sun et al. [13]). Since then, scholars have explored the effect of foreign ownership on CSR from a microscopic perspective. Although the research methods and perspectives are multifarious, the basic conclusions are the same, that is, foreign ownership significantly promotes CSR performance (Wang et al. [14]; Li et al. [15]; Qin et al. [16]).

Some scholars have found that institutional distance has significant correlations with foreign capital flows (Trapczyński et al. [17]; Liu and Xiao [18]; Liu and Meng [19]; Yang and Deng [20]). However, there is no specific investigation on the moderating role of institutional distance in the impact of foreign ownership on CSR. In comparison to preceding studies, the primary contributions of this paper are presented as follows: First of all, from the perspective of foreign ownership, this paper dedicates itself to further investigating the determinants and mechanisms of CSR and enrich the existing research. Secondly, for the measurement of foreign ownership, the extant research is simply to use a dummy variable or qualified foreign institutional investors (QFII) as the proxy of foreign ownership, without specific discussion on the structure of foreign ownership. Using the extant literature for reference, this paper calculates the proportion of the different sources of foreign ownership in the top ten shareholders of A-share listed companies as the proxy of foreign ownership, enriching the existing research methods. Thirdly, many scholars have begun to inquire thoroughly upon the impact of institutional distance in the global economy. Nonetheless, there is no specific empirical study on the role of institutional distance in the relationship between foreign ownership and CSR. This paper constructs panel data models to investigate the moderating role of institutional distance on the impacts of foreign ownership on CSR. Moreover, this paper uses the Euclidean version of the Kogut and Singh [21] distance measurement index (Shenkar [22]) and weighted distance measurement method to calculate legal institutional distance and economic institutional distance. Finally, the empirical results and policy recommendations of this paper are of great practical significance. The conclusions can provide theoretical guidance for China to formulate relevant policies to manage the entry of foreign investment. This makes good sense for improving the CSR performance of companies with foreign ownership and promoting sustainable development.

The remainder of this paper is structured as follows: Section 2 comprehensively reviewed the corresponding literature. Section 3 presents the hypotheses. Section 4 explains the definitions of variables and data sources and establishes empirical models. Section 5 carries out empirical regressions and analyzes the empirical results. Section 6 concludes and propounds some policy recommendations.

\section{Literature Review}

\subsection{Foreign Ownership and CSR}

Many econometricians have explored the determinants of CSR from disparate ownership characteristics. Zhao et al. [23] concluded that the ownership structure had a significant impact on CSR. Jia and Tian [24] found that CSR performance was worse when the senior managers were encouraged by equity incentives. Pei [25] verified that managerial shareholding presented an inverted U-shaped relationship with CSR. Li et al. [26] and Zhao et al. [23] empirically verified that institutional shareholding, managerial shareholding and ownership balance had significant impacts on CSR.

A few scholars have found evidence that foreign trade enterprises can better fulfill their CSR (Taylor [27]; Muller and Kolk [28]; Gu [29]). Moreover, some of the literature further 
examines the impact of FDI on CSR from a macroscopic perspective. Shi [30] found that the scale of FDI inflow was positively correlated with local enterprises' CSR performance. Zheng and Huang [31] found that FDI in upstream industries and downstream industries promoted the enterprises to better fulfill CSR. Huang and Chen [12] concluded that FDI promoted Chinese enterprises' CSR through the channel of supply chain, which was the suppliers of foreign enterprises. Nyuur et al. [32] found evidence the importance of FDI in promoting the CSR of domestic enterprises. Cai et al. [33] concluded that CSR mitigates the information deficiency of foreign investors. From a macro point of view, Nguyen et al. [34] found that FDI had a number of positive and significant impacts on the long-term sustainable development of Vietnam's provinces. Therefore, foreign investors are motivated to supervise the CSR performance of Chinese companies.

Many scholars have been probing into the impact of foreign ownership on CSR. Duan and Li [35] empirically found that the CSR of A-share listed companies had an effect on the QFII's stock selection preferences. Lu [36] demonstrated that foreign shareholding had no positive impact on the CSR of non-renewable energy listed companies. Kang et al. [37] demonstrated that directors from different countries had different influences on CSR investment, which revealed that different countries have different CSR tendencies. Lee et al. [38] and Yan and $\mathrm{Hu}$ [39] concluded that foreign investors tend to pay more attention to the CSR of host countries. Wang et al. [14], Qin et al. [16], Lv and Yin [40] empirically verified that foreign ownership had a significant positive impact on CSR. Dyduch and Krasodomska [41] pointed out that companies with low proportion of foreign shares were the least likely to fully disclose the impact of their business operations on CSR. From the perspective of sustainability, Shin and Park [42] took Korean listed companies as samples and found that there were positive impacts of foreign institutional investors' ownership on the sustainable development of enterprises. Foreign institutions could effectively monitor management, promote enterprise innovation, and promote the long-term sustainable development of enterprises. Choi et al. [43] concluded that foreign owner stakes presented a negative correlation with earnings management in Vietnamese listed companies. Paul et al. [44] used the two dummy variables of QFII investment and cross listing as the proxy of foreign ownership and found that CSR did not present a significant positive correlation with foreign ownership. Gulzar et al. [45] used the dummy variable of foreign institutional investors to measure foreign ownership and demonstrated that, because of the strong political power network in China's listed companies, foreign institutional investors' enthusiasm for further strengthening CSR was relatively low.

\subsection{Institutional Distance and CSR}

Institution is ordinarily regarded as a string of rules in human society, and it is also categorized as formal and informal institution (North [46]). Institutional distance is interpreted as the proxy measure of transnational differences in institutions. Institutional distance is generally considered as an important determinant which hinders transnational economic activities (Pogrebnyakov and Maitland [47]). Furthermore, formal institutional distance (Huang et al. [48]) and informal institutional distance (Ortas et al. [49]) are important determinants of CSR. Keig et al. [50] pointed out that institutional distance had a moderating effect on the CSR performances of different types of multinational corporations. Many works in the literature have thoroughly investigated the impact of institutional distance on CSR through the "theory of liability of foreignness" (Zaheer [51]; Boehe [52]; Ren and Zheng [53]), "theory of empathy effect" (Rayl [54]; Veugelersr [55]; Xiao [56]) and "theory of institution escape" (Gaur and Lu [57]; Aleksynska and Havrylchyk [58]).

Xiao [54] took multinational companies in China's mainland as a sample and found that the economic institutional distance inhibited the CSR of multinational corporations in the host country, while the legal institutional distance significantly promoted the CSR of multinational corporations. Sun et al. [59] found that institutional distance could significantly promote CSR. Shayuti et al. [60] observed that culture and corporate governance interactively affected CSR. Ling [61] took Malaysia as the research background and used 
the fuzzy analysis method to point out that macroeconomic and institutional factors would affect sustainable FDI. Furthermore, sustainable FDI helped Malaysia develop their economy, environment and society in the practice of reasonable governance. Considering the importance of FDI inflow to the sustainable economic development of host countries, Islam et al. [62] examined the relationship between financial development and FDI, with institutional quality as the moderating variable.

Although extensive literature has studied whether institutional differences between different countries have impacts on the CSR performance of enterprises with foreign ownership, the existing research still has some limitations. First of all, the majority of the extant literature considers the impact of FDI on CSR from a macroscopic perspective. In addition, most scholars use QFII investment or a dummy variable as a proxy of foreign ownership. They do not consider the shareholding ratio of foreign ownership. Finally, the impact mechanism of foreign ownership on CSR is a complex process. As it is universally recognized, most of the literature only conducts a simple regression of CSR to foreign ownership, without considering the synthetic impact of other confounding factors, such as institutional distance. There has been no intensive analysis pertaining to elucidate the complex relationship between foreign ownership and CSR, which leads to the limitations of the extant research to a certain extent.

\section{Hypothesis Development}

\subsection{Foreign Ownership and CSR}

Our first research topic underlines the impact of foreign ownership on CSR. Compared to domestic investors, foreign owners potentially provide an increasing intensive channel for affecting CSR. In light of the agency theory, the separation of the management and shareholders produces the agency problem. In addition, foreign owners engender agency conflicts and information asymmetry with the management of companies. As a consequence, this information asymmetry will lead to more investment asymmetry and high-level risk when foreign investors invest in Chinese listed companies. Therefore, compared with domestic investors, foreign investors face a greater information disadvantage due to the existence of geographical distance. Nowadays, CSR has been seen as a necessary tool to reduce information asymmetry (Oh et al. [63]). Therefore, for the sake of the management's supervision, foreign owners tend to demand the management to increase information disclosure and decrease information asymmetry and have a strong motivation to urge enterprises to carry out CSR activities. As a result, according to the stakeholder theory and legitimacy theory, one purpose of CSR disclosure in listed companies is to transfer information to foreign shareholders. Juil et al. [64] concluded that enterprises could meet the various needs of stakeholders by means of CSR actions and send a reliable signal to foreign investors and stakeholders, and thus increase foreign investors' investment and support for host companies. Listed companies disclose CSR information to improve corporate reputation, show its responsible and reliable corporate image to the capital market, alleviate external pressure and thus have better access more financial and technical supports from foreign investors.

Shao and Bao [65] found that foreign enterprises could affect the CSR performance of developing countries through two spillover channels, namely, the competition effect and the demonstration effect. Because CSR originated from developed countries and regions and it has been in practice for decades, developed countries and regions exhibit greater inclination towards the CSR performance of companies. Once the foreign investors from developed countries hold shares of Chinese listed companies, they correspondingly shed light on CSR and strictly spur enterprises to perform CSR when participating in international competition. In addition, in the process of foreign investment, foreign owners will introduce their advanced CSR concept and management experience into China and implement meaningful CSR-engagement change. In a context like this, the impact and shock of the economic integration of China has forced listed companies to abide by the international requirements with respect to CSR, and thus, CSR performance has recently 
been incorporated into the business and political agenda (Tan [66]). Cheung et al. [67] reported that the CSR performance of Chinese companies was improving with their internationalization. Correspondingly, the conclusions of many scholars also echo the view of the role of foreign ownership in promoting CSR performance from multiple perspectives and avenues (Zhou [68]; Paul et al. [44]; Qin et al. [16]). Prior literature provides theoretical foundations for this paper.

Thus, this paper advances Hypothesis 1:

Hypothesis 1 (H1). Foreign ownership has a positive impact on a company's CSR.

\subsection{Foreign Ownership and CSR: The Moderating Role of Legal Institutional Distance}

The legal institutional distance is defined as the difference between the political and legal institutions of countries. Many works of research found evidence that institution was an important variable with which to interpret CSR performance (Peter et al. [69]; Choi et al. [70]). Countries under different legal institutions deal with concerns and conflicts between enterprises, communities and other stakeholders in different ways. Therefore, the quality of supervision and institutional background can largely explain the differences in CSR practice among countries (Liang and Renneboog [71]). Some studies have posited that foreign ownership from countries with strong beliefs in the importance of CSR is the main driving force of CSR in developing countries. Foreign investors in countries with strict laws and regulations can effectively improve the strictness of environmental regulations and enterprise regulatory environment, and solve the concerns of stakeholders regarding unfair competition behavior. Chao and Kumar [72] found that some developed countries or regions (e.g., the United States) had more detailed, transparent laws and better implemented regulations than other countries or regions (e.g., India). The theory of institutional escape holds that foreign owners usually choose countries with a large legal institutional distance to implement investment, including the "escape" from high-quality institution to low-quality institution. Such foreign owners usually come from developed countries with relatively perfect political and economic legal institutions, strict government supervision and a saturated market in the home environment. When foreign investors invest in the high-quality social market, they may show a higher degree of CSR participation, thus promoting enterprises to improve CSR behavior (Alexander et al. [73]). It is already very difficult to carry out institutional arbitrage. Enterprises tend to invest in developing countries with opaque institutions and lax supervision and a large legal institutions distance from their domestic institutions (Zhou et al. [74]). The theory of international investment points out that the foreign investors face the liability of foreignness, because they are unacquainted with the understanding of the host country's political and legal environment. This increases the hazard of investment. However, the disclosure of CSR can bring about a mutual trust between foreign investors and companies and reduce the risk of ownership infringement. Foreign owners will correspondingly exert more pressure on Chinese listed companies to promote the fulfillment of CSR (Yi et al. [75]). Gaur and Lu [57] found that when the institutional distance increased, the survival rate of overseas subsidiaries was more significant if the shareholding ratio of the parent company increased. In addition, the foreign owners of Chinese listed companies are almost always from developed economies. In the meantime, legal responsibility is the basic responsibility of CSR, specifically, legal compliance is the most basic responsibility to be performed by enterprises (Carroll [76]). When the institutional environment of the home country of foreign ownership is obviously better than that of China, Chinese listed companies exhibit a greater inclination for adopting the global strategy and fulfilling CSR. One of the prominent stanchions of many studies is the legitimacy theory. Chinese companies are more inclined to perform the corresponding legal responsibilities and meet the requirements of CSR disclosure from external stakeholders. With the increase of legal institutional distance, the promotion effect will be more significant.

Thus, this paper proposes Hypothesis 2: 
Hypothesis 2 (H2). Legal institutional distance between the home country of foreign ownership and China promotes the positive impact of foreign ownership on CSR.

\subsection{Foreign Ownership and CSR: The Moderating Role of Economic Institutional Distance}

Economic institutional distance refers to the difference among countries in economic development and macroeconomic characteristics. Most of the existing literature uses the Index of Economic Freedom to measure the economic institution of a country or region (Chen et al. [77]). A plethora of scholars has verified the positive correlation between economic freedom and economic development from both theoretical and empirical perspectives (Chen and Chen [78]). When the degree of economic freedom is higher, the degree of economic openness is relatively higher. Moreover, trade barriers and access restrictions are lower. In other words, higher economic freedom makes it more convenient for the home country of foreign ownership to make transnational investment (Shen and Dai [79]). Liu and Deng [80] found that foreign investment would be positively affected by the economic freedom of the host country where the invested enterprise was located. The foreign owners of listed companies in China are mainly from developed countries and regions with a high degree of economic freedom. According to the agency theory and transaction cost theory, when foreign investors hold shares of Chinese listed companies, they are faced with the complex and changeable economic market environment of two countries. Therefore, they will also face serious information asymmetry, resulting in corresponding negotiation and management costs. In addition, compared with developed countries, China's economy is characterized by a lower degree of freedom and strict government control; the daily expenditure and transaction costs are higher. Therefore, foreign capital flow will be at a higher cost, and capital inflow will be greatly restricted. Trade barriers and impediments for foreign capital to enter China will be very high (Chen [81]). For the sake of attracting foreign investment and reducing the risk of foreign investment, listed companies will show more solicitude for CSR performance and accumulate intangible assets and the performance of stakeholders for enterprises. In addition, according to the theory of institutional escape, listed companies with foreign ownership can make use of the heterogeneous resources of home countries of foreign ownership to obtain potential benefits, reduce competitive disadvantage and consumption of slack resources, all of which enable companies to be more capable of fulfilling CSR. Overall, this means that listed companies with foreign owners will act on the behalf of foreign owners to actively fulfill CSR.

Thus, this paper proposes Hypothesis 3:

Hypothesis 3 (H3). Economic institutional distance between the home country of foreign ownership and China promotes the positive impact of foreign ownership on CSR.

\section{Research Design}

\subsection{Dependent Variable}

Rankins CSR Ratings (RKS) principally measures CSR performance by judging the quality of CSR reports. Rankins, as a professional and neutral third-party rating entity, plays a prominent role in providing assistance to investors on the modality and essence of the integral CSR activities of listed companies (Lau et al. [82]). Therefore, this paper uses Rankins CSR Ratings to measure CSR. Referring to ISO26000, Rankins sets four zero-level indicators composed of macrocosm, content, technique and industry to determine the CSR rating. In addition, Rankins adopts expert structured scoring to assess the information derived from annual reports and CSR reports. Rankins CSR Ratings are comprehensive, objective and authoritative.

\subsection{Independent Variable}

The independent variable of this paper is foreign ownership (FO). We used the total proportion of foreign shareholdings held by the top ten shareholders of China's A-share listed companies as a proxy measure of foreign ownership. In recent studies, QFII is usually 
used as a proxy measure for foreign ownership (Li et al. [26]). QFII refers to fund management institutions, insurance companies, securities companies and other asset management institutions outside China approved by China Securities Regulatory Commission to invest in China's securities market. However, QFII does not cover all foreign shareholders Moreover, we cannot obtain the detailed home countries of foreign shareholders and every foreign owner's shareholding ration from the existing QFII shareholding and we are unable to further calculate the institutional distance in detail. As outlined above, different from the existing articles in which QFII is used as the proxy of foreign ownership, this paper calculates the total proportion of foreign ownership in the top ten shareholders of listed companies as the proxy of foreign ownership, so as to obtain more accurate data of every foreign owner's shareholding ratio and corresponding home country and calculate the two types of institutional and further explore the influence mechanism of foreign ownership and CSR.

\subsection{Moderating Variables}

Foreign investors in the top ten shareholders of listed companies may come from different home countries. Therefore, this paper first calculates the distance between different countries and China. We further calculate the weighted distance variables according to the ratio of foreign shareholdings from different home countries in specific year.

\subsubsection{Legal Institutional Distance (LD)}

Following the approach of Song et al. [83], this paper adopts the World Governance Indicators (WGI) constructed and issued by the World Bank to calculate legal institutional distance. WGI measures the effectiveness of government governance and includes six dimensions: control of corruption, government effectiveness, political stability and absence of violence/terrorism, regulatory quality, rule of law, voice and accountability. Specifically, we utilize the Euclidean version of the distance measurement formula of Kogut and Singh [21] to measure the legal institutional distance between a foreign owner's home country and China.

The legal institutional distance between a foreign owner's home country and China is computed as follows:

$$
E L D_{t, j}=\sqrt{\sum_{m=1}^{6}\left(\frac{\left(I_{t, m j}-I_{t, m C}\right)^{2}}{V_{t, m}}\right)}
$$

where $E L D_{t, j}$ represents the legal institutional distance between China and country $j$ in year $t . I_{t, m j}$ represents country $j^{\prime}$ s rating score on the $m$ th governance dimension in year $t$. $I_{t, m C}$ represents the rating score of China on $m$ th governance dimension in year $t . V_{t, m}$ represents the variance of the score of $m$ th governance dimension in year $t$.

According to the ratio of foreign shareholdings from different home countries of year $t$, the weight of each home country of year $t$ is endowed with and the weighted legal institutional distance of year $t$ is correspondingly computed.

The weighted legal institutional distance of listed companies is computed as follows:

$$
L D_{i, t}=\sum_{k=1}^{n} E L D_{t, j} \times \operatorname{Pro}_{t, i j}
$$

where $n$ represents the number of home countries of foreign ownership of the company $i$ in year $t, k$ represents the $k$ th home country of foreign ownership of the company $i$ in year $t, L D_{i, t}$ is the weighted legal institutional distance between foreign ownership of the company $i$ and China in year $t, E L D_{t, j}$ represents the legal institutional distance between the $k$ th home country $j$ of foreign ownership of the company $i$ and China in year $t$, and $\operatorname{Pro}_{t, i j}$ is the proportion of the foreign shareholdings of $k$ th home country $j$ of foreign ownership in total foreign shareholdings of top ten shareholders of the company $i$ in year $t$. 


\subsubsection{Economic Institutional Distance (ED)}

Following Song et al. [83], this paper adopts the Index of Economic Freedom released by the Wall Street Journal and Heritage Foundation to measure the country's economic institution. Specifically, the Index is comprised of 12 indicators of judicial effectiveness, government integrity, tax burden, government spending, fiscal health, property rights, business freedom, labor freedom, monetary freedom, trade freedom, investment freedom and financial freedom. Lower score documents higher economic freedom of the region. To summarize, this paper utilizes the Euclidean version of the distance measurement index of Kogut and Singh [21] to measure the economic institutional distance between a foreign owner's home country and China.

The economic institutional distance between a foreign owner's home country and China is computed as follows:

$$
E E D_{t, j}=\sqrt{\sum_{m=1}^{12}\left(\frac{\left(I_{t, m j}-I_{t, m C}\right)^{2}}{V_{t, m}}\right)}
$$

where $E E D_{t, j}$ represents the economic institutional distance between China and country $j$ in year $t . I_{t, m j}$ represents country $j$ 's rating score on the $m$ th economic freedom dimension in year $t . I_{t, m C}$ represents the rating score of China on $m$ th economic freedom dimension in year $t . V_{t, m}$ represents the variance of the score of $m$ th dimension in year $t$.

According to the ratio of foreign shareholdings from different home countries of year $t$, the weight of each home country of year $t$ is endowed with and the weighted economic institutional distance of year $t$ is correspondingly computed.

The weighted legal economic distance of listed companies is computed as follows:

$$
E D_{i, t}=\sum_{k=1}^{n} E E D_{t, j} \times P r o_{t, i j}
$$

where $n$ represents the number of home countries of foreign ownership of the company $i$ in year $t, k$ represents the $k$ th home country of foreign ownership of the company $i$ in year $t$, $E D_{i . t}$ represents the weighted economic institutional distance between foreign ownership of the company $i$ and China in year $t, E E D_{t, j}$ represents the economic institutional distance between the $k$ th home country of foreign ownership of the company $i$ and China in year $t$, and $\operatorname{Pro}_{t, i j}$ is the proportion of the foreign shareholdings of $k$ th home country $j$ of foreign ownership in total foreign shareholdings in top ten shareholders of the company $i$ in year $j$.

\subsection{Control Variables}

Control variables are selected from a macroscopic perspective and the company perspective. At the macro level, referring to Liu and Zhang [84] and Pengcheng et al. [85], this paper uses GDP per capita (GDP) of each province, where the listed companies are situated to measure the regional economic development level. Furthermore, the marketization index (Market) is chosen as the proxy measure of the extent of regional market opening-up. As to company-specific control variables, following the selection method of control variables of Paul et al. [44], we choose return on equity (ROE) to measure the company's profitability, financial leverage (Lev) to measure the company's long-term solvency and liquidity (Liq) to measure the company's short-term solvency. We also include the proportion of shareholdings of the largest shareholders (Firs) and the property rights (SOE) to consider the effect of ownership structure. We choose Tobin'Q (TobinQ) and price to book ratio (PB)to measure the enterprise value and investment value. In terms of board characteristics, we also choose board size (Board), CEO duality (Dual) and the ratio of independent directors to total board members (Indep) to measure the structure of board. The listing age of the company (Age) and the size of the company (Size) are also selected to measure the basic situation of the company. In the meantime, taking the potential impact of year and industry on CSR into account, we also control for the year and industry fixed effects. Specifically, 
nine-year dummy variables are set based on 2009 and 20 industry dummy variables are coded to distinguish industry sectors provided by CSRC.

The definition of each variable is shown in Table 1.

Table 1. Variable descriptions.

\begin{tabular}{|c|c|c|c|}
\hline Variable & Definition & Symbol & Description \\
\hline Dependent variable & Corporate social responsibility (CSR) & CSR & Rankins CSR Ratings \\
\hline Independent variable & Foreign ownership & $\mathrm{FO}$ & The sum of the proportion of foreign shareholdings in the top ten shareholders \\
\hline Moderating variables & Legal institutional distance & LD & Calculated by Equation (2) \\
\hline \multirow{16}{*}{ Control variables } & Economic institutional distance & ED & Calculated by Equation (4) \\
\hline & The level of economic development & GDP & Natural logarithm of GDP per capita \\
\hline & $\begin{array}{l}\text { Marketization index } \\
\text { Profitability }\end{array}$ & $\begin{array}{l}\text { Market } \\
\text { ROE }\end{array}$ & $\begin{array}{c}\text { Comprehensive score from "China Marketization Index" complied by Gang Fan } \\
\text { Net profit divided by equity }\end{array}$ \\
\hline & Financial leverage & Lev & Total liabilities divided by total assets \\
\hline & Liquidity & Liq & Liquidity ratio \\
\hline & Board size & Board & Natural logarithm of total number of directors \\
\hline & Percentage of independent directors & Indep & The number of independent to the number of all directors. \\
\hline & CEO duality & Dual & 1means the duality of CEO and the chair of board, it takes 1 ; otherwise, it takes 0 \\
\hline & Ownership concentration & Firs & Shareholding ratio of the largest shareholder \\
\hline & The property rights & SOE & 1 for SOEs and 0 for non-SOEs \\
\hline & Tobin'Q & TobinQ & Market value of equity and debts divided by total assets \\
\hline & Price to book ratio & $\mathrm{PB}$ & Market value of equity divided by the book value of equity \\
\hline & The size of company & Size & Natural logarithm of total assets \\
\hline & Listing age of companies & Age & Years from the IPO to the $\mathrm{T}$ year \\
\hline & Year & Year & Dummy variables \\
\hline & Industry & Industry & Dummy variables \\
\hline
\end{tabular}

\subsection{Sample and Data Sources}

Our research sample stems from A-share listed companies with Rankins CSR Ratings for the years 2009-2018. Our research addresses the impacts of foreign ownership on CSR and the moderating role of legal institutional distance and economic institutional distance. The initial samples were processed as follows: First, we removed financial and insurance companies, due to their special disclosure and accounting standards. Secondly, we removed ST and *ST listed companies. Thirdly, we eliminated observations with missing data for vital variables (including companies with missing financial indicators and not disclosed CSR scores in the Rankins Database). Finally, this paper obtains 872 valid sample companies and 5431 firm-year observations. Furthermore, all continuous variables are winsorized at the $1 \%$ and $99 \%$ level for sake of mitigating the impact of potential outliers on the research results.

The data sources of this paper are as follows: (1) The data of CSR rating score derives from the Rankins CSR Ratings database (CSR data can be retrieved from the website http:/ / www. rksratings.cn/. Accessed 5 November 2019); (2)The data of foreign ownership is obtained from Wind database (The raw data of foreign ownership can be retrieved from the website https://www.wind.com.cn/. Accessed 2 January 2020); (3) Legal institutional distance is derived from Global Governance Indicators (WGI) released by the World Bank (WGI data can be retrieved from the website https: / /www.worldbank.org/. Accessed 13 February 2020). The economic institutional distance data comes from the Global Index of Economic Freedom in the annual reports issued by The Wall Street Journal and Heritage Foundation (The data of Global Index of Economic Freedom can be retrieved from the two websites https: / / wallstreet.com/ and https:/ /www.heritage.org/. Accessed 14 February 2020); (4) The data of financial indicators data is available on CSMAR database (The data of financial indicators can be retrieved from the website https:/ / www.gtarsc.com/. Accessed 18 January 2020); (5) GDP is obtained from National Bureau of Statistics of China (NBS)database (GDP data can be retrieved from the website http:/ / www.stats.gov.cn/. Accessed 13 March 2020.); (6) The market index comes from "China Marketization Index" (ISBN: 9787505888944), published by Economic Science Press.

This research used Excel 2016 to sort out, match and screen the data, and used Stata 15 for the subsequent regression analysis and empirical tests.

\subsection{Model Specification}

This paper uses multiple linear regression models to explore the impacts of foreign ownership on CSR and the moderating roles of institutional distance. 
To verify H1, model 1 is specified as follows:

$$
\operatorname{CSR}_{i, t}=\beta_{0}+\beta_{1} F O_{i, t}+\beta_{2} \text { Control }_{i, t}+\text { Year }+ \text { Industry }+\varepsilon
$$

To verify $\mathrm{H} 2$, model 2 is specified as follows:

$$
\operatorname{CSR}_{i, t}=\beta_{0}+\beta_{1} F O_{i, t}+\beta_{2} L D_{i, t}+\beta_{3} F O_{i, t} \times L D_{i, t}+\beta_{4} \text { Control }_{i, t}+\text { Year }+ \text { Industry }+\varepsilon
$$

To verify $\mathrm{H} 3$, model 3 is specified as follows:

$$
\operatorname{CSR}_{i, t}=\beta_{0}+\beta_{1} F O_{i, t}+\beta_{2} E D_{i, t}+\beta_{3} F O_{i, t} \times E D_{i, t}+\beta_{4} \text { Control }_{i, t}+\text { Year }+ \text { Industry }+\varepsilon
$$

where CSR is the overall score of Rankins CSR Ratings. FO is the sum of proportion of foreign ownership in top ten shareholders. $L D$ stands for the weighted legal institutional distance. $E D$ represents the weighted economic distance. Controls specifically incorporates GDP, Market, ROE, Lev, Liq, SOE, Firs, Board, Indep, Dual, TobinQ, PB, Size, Age, Year and Industry. $\beta_{0}$ is the constant term. $\beta 1-\beta 4$ represent the coefficients of independent variable, moderating variables and control variables. Subscripts $i$ and $t$ are for company and year, respectively.

\section{Empirical Results}

\subsection{Descriptive Statistical Analysis}

Table 2 reports the descriptive statistics. The average value of CSR is 38.717 and its standard deviation is 12.332 . The minimum value, median value and maximum value of CSR are 13.330, 36.078 and 89.003, respectively, indicating that the CSRs of different listed companies are quite different and the overall disclosure quality is low. FO has an average value of 0.051 and its maximum value is 0.886 , revealing that the overall level of foreign ownership in China was relatively low over the sample period.

Table 2. Descriptive statistics.

\begin{tabular}{ccccccc}
\hline Variable & Obs & Mean & Std. Dev. & Min & Median & Max \\
\hline CSR & 5431 & 38.717 & 12.332 & 13.330 & 36.078 & 89.003 \\
FO & 5431 & 0.051 & 0.119 & 0 & 0 & 0.886 \\
LD & 5431 & 2.178 & 2.991 & 0 & 0 & 8.315 \\
ED & 5431 & 2.402 & 3.301 & 0 & 0 & 8.916 \\
GDP & 5431 & 11.092 & 0.910 & 9.303 & 11.065 & 19.981 \\
Market & 5431 & 8.207 & 2.015 & -0.3 & 8.31 & 12.219 \\
ROE & 5431 & 0.081 & 0.190 & -7.213 & 0.086 & 1.726 \\
Lev & 5431 & 0.482 & 0.203 & 0.001 & 0.493 & 1.412 \\
Liq & 5431 & 2.191 & 7.111 & 0 & 1.396 & 316.665 \\
SOE & 5431 & 0.621 & 0.485 & 0 & 1 & 1 \\
Dual & 5431 & 0.166 & 0.372 & 0 & 0 & 1 \\
Firs & 5431 & 0.371 & 0.163 & 0.030 & 0.361 & 0.886 \\
Board & 5431 & 2.20 & 0.214 & 1.386 & 2.197 & 2.944 \\
Indep & 5431 & 0.376 & 0.060 & 0.091 & 0.364 & 0.800 \\
TobinQ & 5431 & 2.261 & 1.766 & 0.740 & 1.735 & 31.393 \\
PB & 5431 & 0.835 & 0.869 & 0.033 & 0.686 & 30.394 \\
Size & 5431 & 23.128 & 1.472 & 19.541 & 22.985 & 28.520 \\
Age & 5431 & 16.611 & 5.469 & 1 & 17 & 38 \\
\hline
\end{tabular}

With regard to the moderating variables, the average LD is 2.178 with the maximum value of 8.315 . The average ED is 2.402 with a maximum value of 8.916 . The above shows that the institutional distance between the sample companies and the home countries of foreign ownership is relatively low, but there are great differences between different companies, indicating that the diversity and differentiation between the ownership structure and home countries of foreign ownership are relatively large.

With respect to control variables, the average GDP is 11.092, and the minimum value, median value and maximum value are $9.303,11.065$ and 19.981 , respectively. The average Market is 8.207, and the minimum Market and maximum Market are -0.3 and 12.219 , respectively, showing that China's overall market-oriented development level is relatively high, but some remote areas still have serious problems of slow market-oriented process and unbalanced development. The average ROE is 0.081 , manifesting that the 
business performance of sample enterprises fluctuates greatly. The average Lev is 0.482 , in the range of $45-60 \%$, documenting that the debt-paying ability of sample companies has a strong guarantee. The average Liq is 2.191 , indicating that the liquidity of sample companies is good as a whole. The average Board is 2.2 with the minimum of 1.386 and maximum of 2.944. The average indep is 0.376 , indicating that the average independent director ratio of sample companies is more than one third, fundamentally tallying with the provisions of CSRC. The average value of Dual is 0.166 , which illustrates that $16.7 \%$ of the sample companies have the same chairman and CEO. Firs has an average value of 0.317, which indicates that China's listed companies' ownership are relatively concentrated. The average SOE is 0.621 , manifesting that $62.1 \%$ of the sample companies are state-owned companies. The average TobinQ is 2.261, underscoring that the market value of enterprises is generally higher than their replacement cost. The average value PB is 0.835 , specifically, demonstrating that the sample companies have a high rate of return.

\subsection{Correlation Analysis}

For the purpose of preliminarily verifying our hypotheses, this research conducted correlation analysis. The results of the Pearson correlation coefficients are presented in Table 3. As it is shown, the correlation coefficients between CSR and FO, LD and ED are $0.226,0.303$ and 0.295 at the $1 \%$ significant level, respectively, which verifies the previous hypotheses preliminarily. As for control variables, GDP, Market, ROE, Lev, Board, Indep, Firs, SOE, PB, Size and Age present a positive and significant relationship with CSR. Liq, Dual and TobinQ are present negative and significant relationship with CSR.

Multicollinearity leads to inaccurate estimation of the model. First of all, the Pearson correlation coefficients of each variable in this paper are within 0.5 , preliminarily demonstrating that there is no severe multicollinearity. In further multicollinearity diagnosis, the variance inflation factors (VIF) of model 1 to model 3 are less than 10. Specifically, the maximum VIF of the variables in model 1 to model 3 are 1.99, 2.10 and 1.99, respectively. The regression results of VIF test are shown in Table A1. Consequently, from the results of the Pearson correlation coefficients and VIF diagnosis, we conclude that there is no multicollinearity.

\subsection{Regression Analysis}

In Column 1 of Table 4, the regression results of model 1 are shown. The results show that the coefficient of FO is significant and positive $(p<0.01)$, indicating that foreign investors propose higher requirements for CSR disclosure. Under the pressure of foreign owners and institutional environment, Chinese listed companies will significantly improve CSR disclosure quality in order to obtain legitimacy support and improve corporate reputation. Hypothesis 1 is validated.

Column 2 of Table 4 reports the regression results of model 2. The coefficient of FO $\times$ LD represents the moderating role of legal institutional distance in the impact of foreign ownership on CSR. The interaction coefficient is significantly positive $(p<0.01)$, elucidating that legal institutional distance promotes a positive role in the positive impact of foreign ownership on CSR disclosure quality. With the legal institutional distance between the home countries of foreign ownership and China's listed companies increasing, foreign owners will exert greater pressure on China's listed companies to promote the CSR performance, so as to mitigate the hazard of ownership infringement. According to the theory of institution escape, companies with foreign ownership exhibit greater inclination for adopting a global strategy and increase CSR disclosure quality correspondingly. As outlined above, legal institutional distance further improves and enhances the promotion effect of foreign ownership on CSR. Hypothesis 2 is verified.

Column 3 of Table 4 reports the regression results of model 3. The coefficient of FO $\times \mathrm{ED}$ represents the moderating role of economic institutional distance in the impact of foreign ownership on CSR. The interaction coefficient is significant and positive $(p<0.01)$, documenting that economic institutional distance promotes the positive impact of foreign ownership on 
CSR. As the legal institutional distance between the home countries of foreign ownership and China increases, foreign owners strictly supervise CSR performance, aiming to improve the investment efficiency. Listed companies have a stronger willingness and ability to promote CSR and enhance the promotion effect of foreign ownership on CSR. Hypothesis 3 is verified.

Table 3. Pearson correlation coefficient matrix.

\begin{tabular}{|c|c|c|c|c|c|c|c|}
\hline & CSR & FO & LD & ED & GDP & Markett & ROE \\
\hline CSR & 1 & & & & & & \\
\hline $\mathrm{FO}$ & $0.226^{* * *}$ & 1 & & & & & \\
\hline LD & $0.303^{* * *}$ & $0.588^{* * *}$ & 1 & & & & \\
\hline ED & $0.295^{* * *}$ & $0.597^{* * *}$ & $0.988^{* * *}$ & 1 & & & \\
\hline GDP & $0.143^{* * *}$ & $0.030^{* *}$ & $0.068^{* * *}$ & $0.074^{* * *}$ & 1 & & \\
\hline Market & $0.210^{* * *}$ & $0.124^{* * *}$ & $0.194^{* * *}$ & $0.214^{* * *}$ & $0.269^{* * *}$ & 1 & \\
\hline ROE & $0.028 * *$ & -0.00400 & $0.070^{* * *}$ & $0.064^{* * *}$ & $-0.029^{* *}$ & $0.042 * * *$ & 1 \\
\hline Lev & $0.151^{* * *}$ & $0.071^{* * *}$ & $0.051^{* * *}$ & $0.053^{* * *}$ & 0.0160 & 0.00300 & $-0.143^{* * *}$ \\
\hline Liq & $-0.055^{* * *}$ & 0.00700 & $-0.031^{* *}$ & $-0.034^{* *}$ & -0.00500 & -0.0170 & 0.024 * \\
\hline Board & $0.130^{* * *}$ & $0.076^{* * *}$ & $0.111^{* * *}$ & $0.107^{* * *}$ & $-0.063^{* * *}$ & $-0.106^{* * *}$ & 0.0130 \\
\hline Indep & $0.057^{* * *}$ & $0.046^{* * *}$ & $0.030^{* *}$ & $0.034^{* *}$ & $0.040^{* * *}$ & 0.0120 & -0.00500 \\
\hline Dual & $-0.063^{* * *}$ & 0.00100 & -0.0180 & -0.0150 & 0.023 * & $0.105^{* * *}$ & $0.028^{* *}$ \\
\hline Firs & $0.125^{* * *}$ & $0.122^{* * *}$ & $0.112^{* * *}$ & $0.111^{* * *}$ & 0.0210 & $-0.037^{* * *}$ & $0.036^{* * *}$ \\
\hline SOE & $0.136^{* * *}$ & $0.046^{* * *}$ & $0.117^{* * *}$ & $0.112^{* * *}$ & -0.00500 & $-0.110^{* * *}$ & $-0.062^{* * *}$ \\
\hline TobinQ & $-0.137^{* * *}$ & $-0.036^{* * *}$ & $-0.084^{* * *}$ & $-0.091^{* * *}$ & -0.0110 & $-0.051^{* * *}$ & $0.087^{* * *}$ \\
\hline PB & $0.477^{* * *}$ & $0.261^{* * *}$ & $0.359 * * *$ & $0.364^{* * *}$ & $0.082^{* * *}$ & $0.133^{* * *}$ & $0.083^{* * *}$ \\
\hline Size & $0.094^{* * *}$ & 0.030 ** & $0.075^{* * *}$ & $0.070^{* * *}$ & $0.044^{* * *}$ & $0.144^{* * *}$ & -0.00400 \\
\hline \multirow[t]{2}{*}{ Age } & $0.084^{* * *}$ & $-0.031^{* *}$ & $0.113^{* * *}$ & $0.118^{* * *}$ & $0.086^{* * *}$ & $0.085^{* * *}$ & $-0.064^{* * *}$ \\
\hline & Lev & Liq & Board & Indep & Dual & Firs & SOE \\
\hline Lev & 1 & & & & & & \\
\hline Liq & $-0.253^{* * *}$ & 1 & & & & & \\
\hline Board & $0.091^{* * *}$ & $-0.026^{*}$ & 1 & & & & \\
\hline Indep & $0.050^{* * *}$ & $0.027^{* *}$ & $-0.400^{* * *}$ & 1 & & & \\
\hline Dual & $-0.089^{* * *}$ & $0.034^{* *}$ & $-0.148^{* * *}$ & $0.086^{* * *}$ & 1 & & \\
\hline Firs & $0.058^{* * *}$ & 0.00700 & $0.052^{* * *}$ & $0.063^{* * *}$ & $-0.118^{* * *}$ & 1 & \\
\hline Soe & $0.181^{* * *}$ & $-0.046^{* * *}$ & $0.215^{* * *}$ & -0.00800 & $-0.270^{* * *}$ & $0.317^{* * *}$ & 1 \\
\hline TobinQ & $-0.397^{* * *}$ & $0.111^{* * *}$ & $-0.142^{* * *}$ & $0.027^{* *}$ & $0.129^{* * *}$ & $-0.113^{* * *}$ & $-0.218^{* * *}$ \\
\hline $\mathrm{PB}$ & $0.505^{* * *}$ & $-0.092^{* * *}$ & $0.212^{* * *}$ & $0.125^{* * *}$ & $-0.111^{* * *}$ & $0.263^{* * *}$ & $0.287^{* * *}$ \\
\hline Size & $0.029 * *$ & -0.00700 & -0.0200 & $0.037^{* * *}$ & 0.00900 & $-0.043^{* * *}$ & -0.00300 \\
\hline \multirow[t]{2}{*}{ Age } & $0.203^{* * *}$ & $-0.066^{* * *}$ & $0.034^{* *}$ & -0.00500 & $-0.135^{* * *}$ & $-0.075^{* * *}$ & $0.282^{* * *}$ \\
\hline & TobinQ & Size & PB & Age & & & \\
\hline TobinQ & 1 & & & & & & \\
\hline PB & $-0.422^{* * *}$ & 1 & & & & & \\
\hline Size & $0.068^{* * *}$ & $0.118^{* * *}$ & 1 & & & & \\
\hline Age & $-0.183^{* * *}$ & $0.203^{* * *}$ & $0.094^{* * *}$ & 1 & & & \\
\hline
\end{tabular}

Note: ${ }^{* * *} p<0.01,{ }^{* *} p<0.05,{ }^{*} p<0.1$, respectively. Standard errors are shown in ( ).

\subsection{Robust Tests}

\subsubsection{Propensity Score Matching}

Accounting for self-selection bias, we adopted the propensity score matching model (PSM) to control for differences in company characteristics between companies with and without foreign ownership, thereby estimating the average treatment effect of foreign ownership on CSR to verify the robustness of the above conclusions.

First, we conducted an equilibrium test. The result of conducted equilibrium test elucidated that the pairwise differences of the control variables of the matched sample decreased in magnitude with respect to the unmatched sample and became statistically non-significant, thereby justifying the necessity and effectiveness of PSM. Table A2 presents detailed results of the mean difference test for the pre-matched sample and post-matched sample.

Second, the results of the average treatment effect suggest that self-selection bias causes the estimation results of the ordinary least squares method to be seriously overestimated, and PSM can effectively mitigate this problem (See Table A3). In addition, although the difference of CSR after propensity score matching becomes smaller, the T-value is 4.540 $(p<0.01)$, indicating that foreign ownership has a positive impact on CSR.

Furthermore, the regression results of Table 5 for the matched sample demonstrate that foreign ownership has a positive impact on CSR, and that legal institutional distance and economic institutional distance promote the positive impact of foreign ownership on CSR. 
Table 4. Foreign ownership, institutional distance and corporate social responsibility (CSR).

\begin{tabular}{|c|c|c|c|}
\hline \multicolumn{4}{|c|}{ Dependent Variable: CSR } \\
\hline Variable & (1) & (2) & (3) \\
\hline $\mathrm{FO}$ & $\begin{array}{c}8.206^{* * *} \\
(1.224)\end{array}$ & $\begin{array}{c}90.037^{* * *} \\
(8.296)\end{array}$ & $\begin{array}{c}28.208^{* *} \\
(12.833)\end{array}$ \\
\hline LD & & $1.458^{* * *}$ & \\
\hline $\mathrm{FO} \times \mathrm{LD}$ & & $\begin{array}{c}23.306^{* * *} \\
(2.017)\end{array}$ & \\
\hline ED & & & $\begin{array}{c}0.182^{* * *} \\
(0.056)\end{array}$ \\
\hline $\mathrm{FO} \times \mathrm{ED}$ & & & $\begin{array}{c}4.841^{* * *} \\
(1.827)\end{array}$ \\
\hline GDP & $\begin{array}{c}0.249 \\
(0.163)\end{array}$ & $\begin{array}{c}0.256 \\
(0.161)\end{array}$ & $\begin{array}{c}0.237 \\
(0.163)\end{array}$ \\
\hline Market & $0.504^{* * *}$ & $0.447^{* * *}$ & $0.486^{* * *}$ \\
\hline $\mathrm{ROE}$ & $\begin{array}{l}(0.086) \\
-0.275 \\
(0.757)\end{array}$ & $\begin{array}{c}(0.085) \\
-0.593 \\
(0.747)\end{array}$ & $\begin{array}{c}(0.086) \\
-0.328 \\
(0.756)\end{array}$ \\
\hline Lev & $\begin{array}{c}-3.523^{* * *} \\
(0.919)\end{array}$ & $\begin{array}{c}-3.389^{* * * *} \\
(0.911)\end{array}$ & $\begin{array}{c}-3.167^{* * *} \\
(0.922)\end{array}$ \\
\hline Liq & $\begin{array}{c}-0.038^{*} \\
(0.020)\end{array}$ & $\begin{array}{c}-0.047^{* * *} \\
(0.020)\end{array}$ & $\begin{array}{l}-0.033 \\
(0.020)\end{array}$ \\
\hline Board & $\begin{array}{c}4.174^{* * *} \\
(0.759)\end{array}$ & $\begin{array}{c}4.195^{* * *} \\
(0.748)\end{array}$ & $\begin{array}{c}4.108^{* * *} \\
(0.758)\end{array}$ \\
\hline Indep & $\begin{array}{c}5.844^{* *} \\
(2.617)\end{array}$ & $\begin{array}{c}6.160^{* *} \\
(2.580)\end{array}$ & $\begin{array}{c}5.837^{* *} \\
(2.612)\end{array}$ \\
\hline Dual & $\begin{array}{c}-1.277^{* * * *} \\
(0.386)\end{array}$ & $\begin{array}{c}-1.320^{* * * *} \\
(0.380)\end{array}$ & $\begin{array}{c}-1.293^{* * * *} \\
(0.385)\end{array}$ \\
\hline Firs & $\begin{array}{c}0.124 \\
(0.951)\end{array}$ & $\begin{array}{c}0.238 \\
(0.938)\end{array}$ & $\begin{array}{c}0.025 \\
(0.950)\end{array}$ \\
\hline SOE & $\begin{array}{c}0.986^{* * *} \\
(0.348)\end{array}$ & $\begin{array}{c}0.860^{* *} \\
(0.343)\end{array}$ & $\begin{array}{c}0.931^{* * *} \\
(0.347)\end{array}$ \\
\hline TobinQ & $\begin{array}{c}0.294^{* * *} \\
(0.097)\end{array}$ & $\begin{array}{c}0.274^{* * *} \\
(0.096)\end{array}$ & $\begin{array}{c}0.284^{* * *} \\
(0.097)\end{array}$ \\
\hline PB & $\begin{array}{c}-0.418^{* *} \\
(0.203)\end{array}$ & $\begin{array}{l}-0.291 \\
(0.200)\end{array}$ & $\begin{array}{c}-0.403^{* *} \\
(0.202)\end{array}$ \\
\hline Size & $\begin{array}{c}3.757^{* * *} \\
(0.138)\end{array}$ & $\begin{array}{c}3.549 * * * \\
(0.140)\end{array}$ & $\begin{array}{c}3.644 * * * \\
(0.141)\end{array}$ \\
\hline Age & $\begin{array}{c}-0.141^{* * * *} \\
(0.026)\end{array}$ & $\begin{array}{c}-0.154^{* * * *} \\
(0.026)\end{array}$ & $\begin{array}{c}-0.145^{* * *} \\
(0.026)\end{array}$ \\
\hline Constant & $\begin{array}{c}-77.191^{* * * *} \\
(3.753)\end{array}$ & $\begin{array}{c}-79.307^{* * *} \\
(3.814)\end{array}$ & $\begin{array}{c}-75.871^{* * *} \\
(3.863)\end{array}$ \\
\hline Year & Yes & Yes & Yes \\
\hline Industry & Yes & Yes & Yes \\
\hline $\begin{array}{l}\mathrm{N} \\
\mathrm{R}^{2}\end{array}$ & $\begin{array}{l}5431 \\
0.358\end{array}$ & $\begin{array}{l}5431 \\
0.376\end{array}$ & $\begin{array}{l}5431 \\
0.360\end{array}$ \\
\hline
\end{tabular}

Note: ${ }^{* * *} p<0.01,{ }^{* *} p<0.05,{ }^{*} p<0.1$. Standard errors are shown in ().

\subsubsection{Two-Stage Least Squares Method}

On the one hand, there may be a reverse causal relationship between foreign ownership and CSR. On the other hand, there may be the problem of omitted variables. Although the selection of control variables is able to mitigate the endogenous problem to some degree, the endogeneity caused by the factors that cannot be observed or measured cannot be alleviated by adding the control variables, which may make the regression results biased and inconsistent. In view of the potential endogenous issue in the models, this paper uses the instrumental variable to conduct the two-stage least squares method (2SLS) to estimate the empirical model to deal with the potential endogenous problems.

This paper uses the instrument variable of the industry average of foreign ownership $(\mathrm{InFO})$ for foreign ownership (FO). Table A4 presents the arranged results of the instrumental variable validity test in the first stage of 2SLS. First, the results of underidentification test $(p=0.000)$ indicate that the instrumental variable selected in this paper presents significant correlation with the endogenous variable (FO). Moreover, the F value of weak identification test is 226.753 and is far greater than the usual critical value of 10 , showing that the instrumental variable has passed the weak identification test. As outlined above, the instrumental variable is effective, and the cross terms of instrumental variable and distance variable is also an effective instrumental variable. 
Table 6 demonstrates the 2SLS results of the second stage. The results in Column 1 of Table 6 manifest that the coefficient of FO is 41.427 and significant $(p<0.01)$, documenting foreign ownership (FO) has a positive and significant impact on CSR. The results in Column 2 of Table 6 demonstrate that the coefficient of FO $\times$ LD is 164.304 and significant at the $5 \%$ level, proving that legal institutional distance promotes the positive impact of foreign ownership on CSR. The results in Column 3 of Table 6 demonstrate that the coefficient of $\mathrm{FO} \times \mathrm{ED}$ is $361.083(p<0.05)$, proving that economic institutional distance promotes the positive impact of foreign ownership on CSR.

Table 5. Regression results for post-matched sample.

\begin{tabular}{|c|c|c|c|}
\hline Variable & (1) & (2) & (3) \\
\hline FO & $5.959 * * *$ & $116.890^{* * *}$ & $28.035 *$ \\
\hline \multirow{3}{*}{ LD } & $(1.663)$ & (15.227) & $(16.216)$ \\
\hline & & $0.247^{* * *}$ & \\
\hline & & $(0.082)$ & \\
\hline \multirow[t]{2}{*}{$\mathrm{FO} \times \mathrm{LD}$} & & $19.355^{* * *}$ & \\
\hline & & $(2.452)$ & \\
\hline \multirow[t]{2}{*}{ ED } & & & $0.169^{* *}$ \\
\hline & & & $(0.077)$ \\
\hline \multirow[t]{2}{*}{$\mathrm{FO} \times \mathrm{ED}$} & & & $4.552^{* *}$ \\
\hline & & & $(2.316)$ \\
\hline \multirow[t]{2}{*}{ GDP } & -0.523 & -0.473 & -0.500 \\
\hline & $(0.450)$ & $(0.443)$ & $(0.450)$ \\
\hline \multirow[t]{2}{*}{ Market } & $0.577^{* * *}$ & $0.556^{* * *}$ & $0.584^{* * *}$ \\
\hline & $(0.140)$ & $(0.138)$ & $(0.140)$ \\
\hline \multirow[t]{2}{*}{$\mathrm{ROE}$} & -0.037 & -0.963 & -0.137 \\
\hline & $(1.510)$ & (1.491) & $(1.513)$ \\
\hline \multirow[t]{2}{*}{ Lev } & $-3.116^{* *}$ & $-3.591 * *$ & $-2.955^{*}$ \\
\hline & $(1.516)$ & (1.492) & $(1.516)$ \\
\hline \multirow[t]{2}{*}{$\mathrm{Liq}$} & -0.052 & $-0.084^{* *}$ & -0.041 \\
\hline & $(0.037)$ & $(0.037)$ & $(0.037)$ \\
\hline \multirow[t]{2}{*}{ Board } & $0.399^{* * *}$ & $0.400^{* * *}$ & $0.406^{* * *}$ \\
\hline & $(0.123)$ & $(0.121)$ & $(0.123)$ \\
\hline \multirow[t]{2}{*}{ Indep } & 4.334 & 5.393 & 4.464 \\
\hline & $(4.208)$ & $(4.139)$ & $(4.201)$ \\
\hline \multirow[t]{2}{*}{ Dual } & -0.873 & -0.968 & -0.880 \\
\hline & $(0.631)$ & $(0.621)$ & $(0.630)$ \\
\hline \multirow[t]{2}{*}{ Firs } & -0.955 & -0.800 & -1.044 \\
\hline & (1.511) & $(1.488)$ & $(1.515)$ \\
\hline \multirow[t]{2}{*}{ SOE } & $0.963 *$ & 0.794 & $0.898^{*}$ \\
\hline & $(0.535)$ & $(0.528)$ & $(0.536)$ \\
\hline \multirow[t]{2}{*}{ TobinQ } & 0.147 & 0.158 & 0.146 \\
\hline & $(0.146)$ & $(0.144)$ & $(0.146)$ \\
\hline \multirow[t]{2}{*}{ PB } & -0.147 & -0.077 & -0.124 \\
\hline & $(0.266)$ & $(0.262)$ & $(0.266)$ \\
\hline \multirow[t]{2}{*}{ Size } & $3.425^{* * *}$ & $3.372 * * *$ & $3.416^{* * *}$ \\
\hline & $(0.228)$ & $(0.225)$ & $(0.228)$ \\
\hline \multirow[t]{2}{*}{ Age } & $-0.144^{* * *}$ & $-0.149^{* * *}$ & $-0.144^{* * *}$ \\
\hline & $(0.049)$ & $(0.048)$ & $(0.049)$ \\
\hline \multirow[t]{2}{*}{ Constant } & $-54.522^{* * *}$ & $-53.644^{* * *}$ & $-55.060^{* * *}$ \\
\hline & (7.393) & (7.297) & (7.408) \\
\hline Year & Yes & Yes & Yes \\
\hline Industry & Yes & Yes & Yes \\
\hline $\mathrm{N}$ & 2205 & 2205 & 2205 \\
\hline $\mathrm{R}^{2}$ & 0.278 & 0.302 & 0.281 \\
\hline
\end{tabular}

Note: ${ }^{* * *} p<0.01,{ }^{* *} p<0.05, * p<0.1$. Standard errors are shown in ( ).

\subsubsection{Alternative Measures of Independent Variable and Moderating Variables}

On the one hand, most of the foreign ownership of A-share listed companies in China comes from the same country or region. On the other hand, even though there are a number of home countries of foreign ownership, the proportion of large shareholdings is very great. In response to this situation, this paper employs the largest foreign shareholdings of China's A share listed companies (LarFO) as an alternative measure of foreign ownership (FO). Correspondingly, this paper replaces the previous weighted legal institutional distance and weighted economic institutional distance with the legal distance and economic institutional distance between the home country of the largest foreign shareholder and China, respectively. Then, this paper conduct regression analysis again with the alternative measures of 
independent variable and moderating variables. As reported in Table 7, the conclusions are essentially unchanged and consistent with our previous hypotheses, illustrating that the conclusion of this paper is robust.

Table 6. The results of two stage least square (the second stage of 2SLS).

\begin{tabular}{|c|c|c|c|}
\hline \multicolumn{4}{|c|}{ Dependent Variable: CSR } \\
\hline Variable & (1) & (2) & (3) \\
\hline FO & $\begin{array}{l}41.427^{* * *} \\
(6.546)\end{array}$ & $\begin{array}{c}744.644^{* * *} \\
(284.631)\end{array}$ & $\begin{array}{c}2624.791^{* *} \\
(1059.393)\end{array}$ \\
\hline LD & & $\begin{array}{c}9.982 * * * \\
(3.790)\end{array}$ & \\
\hline $\mathrm{FO} \times \mathrm{LD}$ & & $\begin{array}{c}164.304^{* *} \\
(65.955)\end{array}$ & \\
\hline ED & & & $\begin{array}{c}20.232 * * \\
(8.193)\end{array}$ \\
\hline $\mathrm{FO} \times \mathrm{ED}$ & & & $\begin{array}{c}361.083^{* *} \\
(146.505)\end{array}$ \\
\hline GDP & $\begin{array}{c}1.037^{* * *} \\
(0.174)\end{array}$ & $\begin{array}{c}1.208^{* * *} \\
(0.196)\end{array}$ & $\begin{array}{c}1.498^{* * *} \\
(0.397)\end{array}$ \\
\hline Market & $0.583^{* * *}$ & $0.805^{* * *}$ & $2.066^{* * *}$ \\
\hline $\mathrm{ROE}$ & $\begin{array}{l}(0.091) \\
-0.979 \\
(0.856)\end{array}$ & $\begin{array}{c}(0.121) \\
0.598 \\
(1.454)\end{array}$ & $\begin{array}{c}(0.617) \\
-2.221 \\
(3.177)\end{array}$ \\
\hline Lev & $\begin{array}{c}-5.386^{* * *} \\
(0.953)\end{array}$ & $\begin{array}{c}-6.499^{* * *} \\
(1.281)\end{array}$ & $\begin{array}{c}-14.058^{* * *} \\
(4.313)\end{array}$ \\
\hline $\mathrm{Liq}$ & $\begin{array}{c}-0.072^{* * *} \\
(0.022)\end{array}$ & $\begin{array}{l}-0.023 \\
(0.036)\end{array}$ & $\begin{array}{l}-0.298 \\
(0.215)\end{array}$ \\
\hline Board & $\begin{array}{c}2.154^{* *} \\
(0.847)\end{array}$ & $\begin{array}{c}1.369 \\
(1.440)\end{array}$ & $\begin{array}{l}-0.995 \\
(3.117)\end{array}$ \\
\hline Indep & $\begin{array}{l}1.844 \\
(2.883)\end{array}$ & $\begin{array}{l}-2.706 \\
(5.404)\end{array}$ & $\begin{array}{c}0.904 \\
(9.458)\end{array}$ \\
\hline Dual & $\begin{array}{c}-1.075^{* *} \\
(0.427)\end{array}$ & $\begin{array}{l}-0.600 \\
(0.627)\end{array}$ & $\begin{array}{l}-1.436 \\
(1.090)\end{array}$ \\
\hline Firs & $\begin{array}{c}-2.248^{* *} \\
(1.056)\end{array}$ & $\begin{array}{l}-2.468 \\
(1.586)\end{array}$ & $\begin{array}{l}-1.679 \\
(3.145)\end{array}$ \\
\hline SOE & $\begin{array}{l}0.686^{*} \\
(0.368)\end{array}$ & $\begin{array}{c}1.580^{* * *} \\
(0.580)\end{array}$ & $\begin{array}{c}0.966 \\
(1.055)\end{array}$ \\
\hline TobinQ & $\begin{array}{l}0.225 * * \\
(0.105)\end{array}$ & $\begin{array}{l}0.281^{* *} \\
(0.127)\end{array}$ & $\begin{array}{l}-0.018 \\
(0.276)\end{array}$ \\
\hline PB & $\begin{array}{c}0.249 \\
(0.179)\end{array}$ & $\begin{array}{c}0.081 \\
(0.307)\end{array}$ & $\begin{array}{l}-1.205 \\
(0.850)\end{array}$ \\
\hline Size & $\begin{array}{c}3.301 * * * \\
(0.213)\end{array}$ & $\begin{array}{c}4.092^{* * *} \\
(0.265)\end{array}$ & $\begin{array}{c}4.677^{* * *} \\
(0.515)\end{array}$ \\
\hline Age & $\begin{array}{c}0.010 \\
(0.028)\end{array}$ & $\begin{array}{l}0.119^{*} \\
(0.065)\end{array}$ & $\begin{array}{c}0.188 \\
(0.148)\end{array}$ \\
\hline Constant & $-58.890^{* * *}$ & $\begin{array}{c}-59.426^{* * *} \\
(9.010)\end{array}$ & $\begin{array}{c}38.428 \\
(50.267)\end{array}$ \\
\hline Year & Yes & Yes & Yes \\
\hline Industry & Yes & Yes & Yes \\
\hline $\begin{array}{l}\mathrm{N} \\
\mathrm{R}^{2}\end{array}$ & $\begin{array}{l}5431 \\
0.190\end{array}$ & $\begin{array}{c}5431 \\
-0.802\end{array}$ & $\begin{array}{c}5431 \\
-0.437\end{array}$ \\
\hline
\end{tabular}

Note: ${ }^{* * *} p<0.01,{ }^{* *} p<0.05,{ }^{*} p<0.1$. Standard errors are shown in ().

Table 7. Regression results of robust tests (alternative measures of independent variable and moderating variables).

\begin{tabular}{cccc}
\hline Variable & $\mathbf{( 1 )}$ & $\mathbf{( 2 )}$ & $\mathbf{( 3 )}$ \\
\hline LarFO & $8.114^{* * *}$ & $95.261^{* * *}$ & $(9.047)$ \\
LD & $(1.257)$ & $(8.703)$ & \\
LarFO $\times$ LD & & $1.480^{* * *}$ & $(0.118)$ \\
ED & & $24.580^{* * *}$ & $(2.122)$ \\
& & & $0.478^{* * *}$ \\
\hline
\end{tabular}


Table 7. Cont.

\begin{tabular}{|c|c|c|c|}
\hline Variable & (1) & (2) & (3) \\
\hline $\mathrm{LarFO} \times \mathrm{ED}$ & & & $\begin{array}{c}5.779 * * * \\
(1.940)\end{array}$ \\
\hline GDP & $\begin{array}{c}0.248 \\
(0.163)\end{array}$ & $\begin{array}{c}0.257 \\
(0.161)\end{array}$ & $\begin{array}{c}0.235 \\
(0.163)\end{array}$ \\
\hline Market & $\begin{array}{c}0.508^{* * *} \\
(0.086)\end{array}$ & $\begin{array}{c}0.449^{* * *} \\
(0.085)\end{array}$ & $\begin{array}{c}0.488^{* * *} \\
(0.086)\end{array}$ \\
\hline ROE & $\begin{array}{l}-0.266 \\
(0.757)\end{array}$ & $\begin{array}{l}-0.590 \\
(0.747)\end{array}$ & $\begin{array}{l}-0.330 \\
(0.756)\end{array}$ \\
\hline Lev & $\begin{array}{c}-3.536^{* * *} \\
(0.919)\end{array}$ & $\begin{array}{c}-3.3911^{* * *} \\
(0.911)\end{array}$ & $\begin{array}{c}-3.141^{* * *} \\
(0.923)\end{array}$ \\
\hline $\mathrm{Liq}$ & $\begin{array}{c}-0.038 * \\
(0.020)\end{array}$ & $\begin{array}{c}-0.047^{* *} \\
(0.020)\end{array}$ & $\begin{array}{l}-0.032 \\
(0.020)\end{array}$ \\
\hline Board & $\begin{array}{c}4.183^{* * * *} \\
(0.758)\end{array}$ & $\begin{array}{c}4.182^{* * * *} \\
(0.748)\end{array}$ & $\begin{array}{c}4.115^{* * *} \\
(0.758)\end{array}$ \\
\hline Indep & $\begin{array}{c}5.857^{* *} \\
(2.617)\end{array}$ & $\begin{array}{c}6.246^{* *} \\
(2.579)\end{array}$ & $\begin{array}{c}5.880^{* *} \\
(2.612)\end{array}$ \\
\hline Dual & $\begin{array}{c}-1.272^{* * *} \\
(0.386)\end{array}$ & $\begin{array}{c}-1.305^{* * *} \\
(0.380)\end{array}$ & $\begin{array}{c}-1.288^{* * *} \\
(0.385)\end{array}$ \\
\hline Firs & $\begin{array}{c}0.099 \\
(0.952)\end{array}$ & $\begin{array}{c}0.218 \\
(0.938)\end{array}$ & $\begin{array}{c}0.011 \\
(0.950)\end{array}$ \\
\hline SOE & $\begin{array}{c}0.977^{* * *} \\
(0.348)\end{array}$ & $\begin{array}{c}0.860^{* *} \\
(0.343)\end{array}$ & $\begin{array}{c}0.922^{* * *} \\
(0.347)\end{array}$ \\
\hline TobinQ & $\begin{array}{c}0.297^{* * *} \\
(0.097)\end{array}$ & $\begin{array}{c}0.274^{* * *} \\
(0.096)\end{array}$ & $\begin{array}{c}0.284^{* * * *} \\
(0.097)\end{array}$ \\
\hline PB & $\begin{array}{c}-0.422 * * \\
(0.203)\end{array}$ & $\begin{array}{l}-0.286 \\
(0.200)\end{array}$ & $\begin{array}{c}-0.403^{* *} \\
(0.202)\end{array}$ \\
\hline Size & $\begin{array}{c}3.766^{* * *} \\
(0.138)\end{array}$ & $\begin{array}{c}3.547^{* * *} \\
(0.139)\end{array}$ & $\begin{array}{c}3.644^{* * *} \\
(0.141)\end{array}$ \\
\hline Age & $\begin{array}{c}-0.139^{* * *} \\
(0.026)\end{array}$ & $\begin{array}{c}-0.153^{* * *} \\
(0.026)\end{array}$ & $\begin{array}{c}-0.145^{* * *} \\
(0.026)\end{array}$ \\
\hline Constant & $\begin{array}{c}-77.426^{* * *} \\
(3.752)\end{array}$ & $\begin{array}{c}-79.373^{* * *} \\
(3.814)\end{array}$ & $\begin{array}{c}-76.182^{* * *} \\
(3.864)\end{array}$ \\
\hline Year & Yes & Yes & Yes \\
\hline Industry & Yes & Yes & Yes \\
\hline $\mathrm{N}$ & 5431 & 5431 & 5431 \\
\hline $\mathrm{R}^{2}$ & 0.357 & 0.376 & 0.360 \\
\hline
\end{tabular}

Note: ${ }^{* * *} p<0.01,{ }^{* *} p<0.05,{ }^{*} p<0.1$. Standard errors are shown in ( ).

\section{Conclusions and Policy Implications}

\subsection{Conclusions}

With the acceleration of reform, opening-up and globalization, foreign ownership has a significant impact on CSR. Moreover, a plethora of empirical studies show that institutional distance and geographic distance also play an important role in international capital flows. This paper utilizes panel data of CSR disclosure quality of A-share listed companies in China for the period of 2009 to 2018 as a sample to examine the impacts of foreign ownership on CSR and the moderating role of legal institutional distance and economic institutional distance in the relationship between the foreign ownership and CSR.

The dominating conclusions are listed as follows: First, foreign ownership has a significant positive impact on CSR, which is in accordance with Hypothesis 1. Second, legal institutional distance promotes the positive impact of foreign ownership on CSR, which is in accordance with Hypothesis 2; Third, economic institutional distance promotes the positive impact of foreign ownership on CSR, which is in accordance with Hypothesis 3. Finally, the results of two stage least square (2SLS) and robust test of alternative measures are consistent with our prior conclusions, proving our conclusions are robust.

\subsection{Policy Implications}

Although CSR in China is increasingly prevailing as a whole, there is still persisting a great disparity in comparison to developed countries. With the phenomenon of foreign holding shares of listed companies becoming more and more common, how to use foreign capital to improve CSR disclosure quality has become a focal point. In accordance with the research conclusions, this paper advances the following feasible policy:

Firstly, the Chinese government should actively guide listed companies to improve their ownership structure and reasonably introduce foreign capital, further promoting 
companies to actively assume CSR to achieve sustainable development. In the reform of China's securities market, the financial regulatory authorities should vigorously improve the legal and economic environment, improve the institution design and provide sufficient legal guarantee for the active and reasonable introduction of foreign capital. At the same time, in order to achieve the goal of sustainable development, enterprises must take the initiative to fulfill CSR and avoid the risk of CSR brought by foreign investment (Kang et al. [37]; Lee et al. [38]; Yan and Hu [39]). In this way, China's companies can further standardize the information disclosure quality, improve the CSR performance and finally promote the sound development of China's economy.

Secondly, Chinese listed companies should make reasonable differential strategies and plans based on the institutional differences between the home countries of foreign ownership and China. Specifically, listed companies should coordinate the conflicts of interest between different foreign shareholders, make all-out efforts to meet the requirements of foreign owners, enhance mutual trust between foreign investors and fully protect the interests of foreign shareholders. Therefore, China's listed enterprises ought to strengthen internal control and supervision to prevent the management from opportunistic behavior.

Finally, legal institutional distance and the economic institutional distance promote the positive impact of foreign ownership on CSR. Therefore, China's listed enterprises should actively learn from the CSR strategy of developed economies. Chinese companies with foreign ownership should adopt more convenient ways of communication with foreign investors to improve information transparency and reduce information costs, aiming to further improve CSR performance.

\subsection{Research Limitations and Prospect}

For one thing, this paper extends the extant research pertaining to foreign ownership and CSR. For another thing, it is completely fundamental for revealing the motivation of companies with foreign ownership to fulfill CSR. However, this paper still has the following limitations: First, confined to the availability of data, the measure of foreign ownership only employs the total proportion of foreign ownership of the top ten shareholders. However, the shares of listed companies in China are relatively concentrated, and the proportion of the top ten shareholders accounts for the majority of the total shares. According to the data, except foreign ownership of the top ten shareholders, the shareholding proportion of other foreign shareholders is basically less than $0.5 \%$. Therefore, we believe that the potential limitations of our data have little impact on the conclusions of the research. Second, the measures of legal institutional distance and economic institutional distance are not unified in the academia at present. This paper uses the Euclidean distance measurement method that has been widely used in recent years. Nevertheless, this kind of measurement may neglect some factors in the measurement of differences, leading to the measurement not being completely accurate. In the future, we should continue to perfect the distance measurement model. Finally, investigation on the impact path of foreign ownership on CSR is still not in-depth, which is a future research direction.

Author Contributions: Conceptualization, M.G.; Data curation, C.Z.; Formal analysis, C.Z.; Funding acquisition, M.G.; Methodology, M.G.; Project administration, M.G.; Software, C.Z.; Supervision, M.G.; Validation, C.Z.; Visualization, C.Z.; Writing-original draft, C.Z.; Writing-review and editing, M.G. All authors have read and agreed to the published version of the manuscript.

Funding: This study is funded by Independent Innovation Fund of Tianjin University (No.: 2020XSC0075). The funders had no role in the design of the study; in the collection, analyses, or interpretation of data; in the writing of the manuscript, or in the decision to publish the results.

Institutional Review Board Statement: Not applicable.

Informed Consent Statement: Not applicable.

Data Availability Statement: The data used in this study are available through the links shown in Section 4.5. 
Conflicts of Interest: The authors declare no conflict of interest.

Appendix A. The VIF Results of Model 1-3

Table A1. The VIF result of Model 1-Model 3.

\begin{tabular}{ccccccc}
\hline & \multicolumn{2}{c}{ Model 1 } & \multicolumn{2}{c}{ Model 2 } & \multicolumn{2}{c}{ Model 3 } \\
\hline Variables & VIF & $\mathbf{1 / V I F}$ & VIF & $\mathbf{1 / V I F}$ & VIF & 1/VIF \\
\hline FO & 1.10 & 0.906015 & 1.57 & 0.638775 & 1.11 & 0.903687 \\
LD & & & 1.73 & 0.576864 & & \\
ED & & & & & 1.23 & 0.813475 \\
GDP & 1.04 & 0.963221 & 1.04 & 0.963220 & 1.04 & 0.963185 \\
Market & 1.18 & 0.845121 & 1.20 & 0.835564 & 1.19 & 0.837283 \\
TobinQ & 1.36 & 0.734019 & 1.36 & 0.733768 & 1.36 & 0.734009 \\
ROE & 1.08 & 0.927473 & 1.08 & 0.925799 & 1.08 & 0.925099 \\
SOE & 1.32 & 0.757061 & 1.33 & 0.754476 & 1.32 & 0.756345 \\
Board & 1.31 & 0.762438 & 1.31 & 0.761700 & 1.31 & 0.762111 \\
Firs & 1.26 & 0.794042 & 1.26 & 0.793941 & 1.26 & 0.793965 \\
Indep & 1.23 & 0.813872 & 1.23 & 0.813816 & 1.26 & 0.796763 \\
Lev & 1.59 & 0.628001 & 1.62 & 0.616222 & 1.60 & 0.625378 \\
Size & 1.99 & 0.502971 & 2.10 & 0.475955 & 1.99 & 0.501445 \\
Age & 1.18 & 0.850867 & 1.18 & 0.846019 & 1.19 & 0.842702 \\
Dual & 1.11 & 0.904376 & 1.11 & 0.904332 & 1.18 & 0.848019 \\
Liq & 1.07 & 0.930250 & 1.08 & 0.928088 & 1.08 & 0.929697 \\
PB & 1.07 & 0.936165 & 1.07 & 0.935958 & 1.07 & 0.935981 \\
Mean VIF & 1.26 & & 1.33 & & 1.27 & \\
\hline
\end{tabular}

\section{Appendix B. The Regression Results of Robust Tests}

Table A2. Mean difference test for pre-matched sample and post-matched sample.

\begin{tabular}{ccccccc}
\hline \multirow{2}{*}{ Variables } & \multicolumn{3}{c}{ Pre-Matched Sample } & \multicolumn{3}{c}{ Post-Matched Sample } \\
\cline { 2 - 6 } & Treated & Control & $t$-Test & Treated & Control & $t$-Test \\
\hline GDP & 11.004 & 11.023 & $-2.770^{* * *}$ & 11.002 & 11.000 & 0.13 \\
Market & 8.736 & 7.921 & $14.490^{* * *}$ & 8.729 & 8.579 & 0.430 \\
ROE & 0.098 & 0.072 & $4.800^{* * *}$ & 0.102 & 0.088 & 0.090 \\
Lev & 0.495 & 0.475 & $3.430^{* * *}$ & 0.495 & 0.487 & 1.190 \\
Liq & 1.894 & 2.352 & $-2.270^{* *}$ & 1.904 & 2.516 & -0.850 \\
Board & 9.547 & 9.081 & $8.100^{* * *}$ & 9.523 & 9.453 & 0.940 \\
Indep & 0.378 & 0.374 & $2.130^{* *}$ & 0.378 & 0.384 & -0.660 \\
Dual & 0.159 & 0.170 & $-5.130^{* * *}$ & 0.159 & 0.145 & 1.220 \\
Firs & 0.395 & 0.358 & $7.970^{* * *}$ & 0.391 & 0.403 & -1.110 \\
SOE & 0.696 & 0.581 & $8.330^{* * *}$ & 0.692 & 0.685 & 0.530 \\
TobinQ & 2.067 & 2.366 & $-5.980^{* * *}$ & 2.075 & 2.048 & 0.450 \\
PB & 0.919 & 0.789 & $5.280^{* * *}$ & 0.919 & 0.931 & -0.380 \\
Size & 23.827 & 22.750 & $27.450^{* * *}$ & 23.787 & 23.841 & -1.070 \\
Age & 17.431 & 16.168 & $8.170^{* * *}$ & 17.434 & 17.113 & 1.200 \\
\hline
\end{tabular}

Note: ${ }^{* * *}$ and ${ }^{* *}$ indicates statistical significance at the $1 \%, 5 \%$ and $10 \%$ level, respectively.

Table A3. Average treatment effect.

\begin{tabular}{ccccc}
\hline Treatment Effect & Treated & Controls & Difference & T-Stat \\
\hline OLS & 43.404 & 36.184 & 7.220 & $21.440^{* * *}$ \\
ATT & 43.171 & 40.539 & 2.632 & $4.540^{* * *}$ \\
ATU & 36.1849 & 37.729 & 1.545 & \\
ATE & & & 1.924 & \\
\hline
\end{tabular}

Note: ${ }^{* * *} p<0.01$. 
Table A4. The results of instrumental variable validity test (The first age of 2SLS).

\begin{tabular}{cc}
\hline \multicolumn{2}{c}{ Underidentification Test } \\
\hline $\begin{array}{c}\text { Anderson canon. corr.LM statistic } \\
\text { Chi-sq(1) P value }\end{array}$ & 226.753 \\
\multicolumn{2}{c}{ Weak Identification Test } \\
\hline (Cragg-Donald Wald F statistic) & 235.936 \\
\hline
\end{tabular}

\section{References}

1. Menguc, B.; Ozanne, L.K. Challenges of the "green imperative": A natural resource-based approach to the environmental orientation-business performance relationship. J. Bus. Res. 2005, 58, 430-438. [CrossRef]

2. Peloza, J.; Shang, J. How can corporate social responsibility activities create value for stakeholders? A systematic review. J. Acad. Mark. Sci. 2011, 39, 117-135. [CrossRef]

3. Wang, H.; Han, B. Social responsibility, internal control and sustainable development of enterprises: An Empirical Analysis Based on A-share main board listed companies. J. Beijing Technol. Bus. Univ. 2016, 1, 1-10. (In Chinese)

4. Qu, Y.; Yu, Y.; Appolloni, A.; Li, M.; Liu, Y. Measuring green growth efficiency for Chinese manufacturing industries. Measuring Green Growth Efficiency for Chinese Manufacturing Industries. Sustainability 2017, 9, 637. [CrossRef]

5. Hristov, I.; Chirico, A.; Appolloni, A. Sustainability Value Creation, Survival, and Growth of the Company: A Critical Perspective in the Sustainability Balanced Scorecard (SBSC). Sustainability 2019, 11, 2119. [CrossRef]

6. Song, Y.; Deng, R.; Liu, R.; Peng, Q. Effects of special economic zones on FDI in emerging economies: Does institutional quality matter? Sustainability 2020, 12, 8409. [CrossRef]

7. Wang, C.N.; Lee, A.P. Application of multi-criteria decision-making model and GM $(1,1)$ theory for evaluating efficiency of FDI on economic growth: A case study in developing countries. Sustainability 2019, 11, 2389. [CrossRef]

8. Li, W. Ownership Type, Political Rent-seeking and Corporate Social Disclosure, An Analytical Framework. Account. Res. 2012, 1, 81-88, 97. (In Chinese)

9. Sun, Y.; Tao, L. Ownership structure, corporate governance and corporate social responsibility. Zhejiang Acad. J. 2019, 1, 111-123. (In Chinese)

10. Gloßner, S. Investor Horizons, Long-Term Blockholders, and Corporate Social Responsibility. J. Bank. Financ. 2019, 103, 78-97. [CrossRef]

11. Lin, L.; Lou, G. The Environmental Performance of Foreign Direct Investment Firms, The Case of Shanghai. China Econ. Q. 2014, 13, 515-536. (In Chinese)

12. Huang, W.; Chen, Z. Foreign investment, supply chain pressure and China's corporate social responsibility. Manag. World 2015, 2, 91-100, 132. (In Chinese)

13. Sun, P.; Jiang, W.; Chen, W. Liberalization of foreign investment, technological distance and export of Chinese Enterprises-Based on the perspective of upstream and downstream industry association. Manag. World 2015, 11, 53-69. (In Chinese)

14. Wang, H.; Lv, X.; Lin, W. The Effect of Foreign Equity Participation, Executive Ownership, Institutional Ownership on Corporate Social Responsibility-Based on the Empirical Test of A-share Public Companies in China. Account. Res. 2014, 8, 81-87, 97. (In Chinese)

15. Li, C.; Liu, B.; Zhou, P.; Zhang, X. QFII and Corporate Information Disclosure. J. Financ. Res. 2018, 12, 138-156. (In Chinese)

16. Qin, X.; Wang, Z.; Zhao, H. Corporate Governance and CSR Disclosures-Evidence from the SMEs of Chi Next Board. Manag. Rev. 2018, 30, 188-200. (In Chinese)

17. Trapczyński, P.; Halaszovich, T.F.; Piaskowska, D. The role of perceived institutional distance in foreign ownership level decisions of new MNEs. J. Bus. Res. 2019, 108, 435-449. [CrossRef]

18. Liu, W.; Xiao, G. Cultural Distance, Institutional Effects and Cross-border Equity Investment. Bus. Manag. J. 2015, 37, 171-182. (In Chinese)

19. Liu, X.; Meng, Y. A Study on Institutional Distance and Duration of Cross-Border Mergers and Acquisitions by Chinese Firms. Bus. Manag. J. 2019, 41, 22-39. (In Chinese)

20. Yang, H.; Deng, T. Market Distance, Market Size and Market Entry Sequence of Chinese Outward Foreign Direct Investment. Bus. Manag. J. 2017, 39, 20-34. (In Chinese)

21. Kogut, B.; Singh, H. The Effect of National Culture on the Choice of Entry Mode. J. Int. Bus. Stud. 1988, 19, 411-432. [CrossRef]

22. Shenkar, O. Cultural Distance Revisited, Towards a More Rigorous Conceptualization and Measurement of Cultural Differences. J. Int. Bus. Stud. 2001, 32, 519-535. [CrossRef]

23. Zhao, X.; Li, M.; Zhang, M. Research on the impact of ownership structure and executive characteristics on environmental information disclosure. Friends Account. 2019, 12, 120-125. (In Chinese)

24. Jia, X.; Tian, G. Executive Compensation Incentive, Agency Cost and Corporate Social Responsibility. Commun. Financ. Account. 2019, 33, 15-19. (In Chinese)

25. Pei, Y. The Effect of Managerial Ownership on Corporate Social Responsibility; Hunan University: Hunan, China, 2018. (In Chinese) 
26. Li, Z.; Wang, P.; Wu, T. Do foreign institutional investors drive corporate social responsibility? Evidence from listed firms in china. J. Bus. Financ. Account. 2020, in press. [CrossRef]

27. Taylor, C.G. Globalization and the Environment, Determinants of Firm Self-Regulation in China. J. Int. Bus. Stud. 2001, 32, 439-458.

28. Muller, A.; Kolk, A. Extrinsic and Intrinsic Drivers of Corporate Social Performance, Evidence from Foreign and Domestic Firms in Mexico. J. Manag. Stud. 2001, 47, 1-26. [CrossRef]

29. Gu, W. Research on corporate social responsibility and China's foreign trade relations. China Price 2012, 6, 58-60. (In Chinese)

30. Shi, J. Analysis of the reasons and Countermeasures for the weakening of the social responsibility of foreign-funded enterprises. China Econ. 2011, 12, 46-48. (In Chinese)

31. Zheng, S.; Huang, L. Impact of Foreign Direct Investment Entry on Corporate Social Responsibility—Based on Intra-industry and Inter-industry Spillover Effects. J. Int. Trade 2018, 5, 116-129. (In Chinese)

32. Nyuur, R.B.; Ofori, D.F.; Debrah, Y.A. The Impact of FDI Inflow on Domestic Firms' Uptake of CSR Activities, The Moderating Effects of Host Institutions. Thunderbird Int. Bus. Rev. 2016, 58, 147-159. [CrossRef]

33. Cai, W.; Lee, E.; Xu, A.L.; Zeng, C. Does corporate social responsibility disclosure reduce the information disadvantage of foreign investors? J. Int. Account. Audit. Tax. 2019, 34, 12-29. [CrossRef]

34. Nguyen, H.V.; Phan, T.T.; Lobo, A. Debunking the myth of foreign direct investment toward long-term sustainability of a developing country: A transaction cost analysis approach. Sustainability 2019, 11, 4569. [CrossRef]

35. Duan, Y.; Li, F. A Study on QFII Shareholding Preferences, Based on the Perspective of Social Responsibility. Nankai Bus. Rev. 2014, 17, 44-50, 94. (In Chinese)

36. Lu, M. Foreign Ownership, Corporate Social Responsibility and Firm's Value-Based on Researching of Non-Renewable Resources Listing Corporations; Jinan University: Jinan, China, 2014. (In Chinese)

37. Kang, Y.S.; Huh, E.; Lim, M.H. Effects of foreign directors' nationalities and director types on corporate philanthropic behavior: Evidence from Korean firms. Sustainability 2019, 11, 3132. [CrossRef]

38. Lee, S.; Kim, I.; Hong, C.H. Who values corporate social responsibility in the Korean stock market? Sustainability 2019, $11,5924$. [CrossRef]

39. Yan, Y.; $\mathrm{Hu}, \mathrm{W}$. Does foreign direct investment affect tropospheric $\mathrm{SO}_{2}$ emissions? A spatial analysis in eastern China from 2011 to 2017. Sustainability 2020, 12, 2878. [CrossRef]

40. Lv, M.; Yin, S. The impact of equity nature on Corporate Social Responsibility, An Empirical Study Based on China's A-share listed companies. Financ. Account. Mon. 2015, 24, 38-42. (In Chinese)

41. Dyduch, J.; Krasodomska, J. Determinants of corporate social responsibility disclosure: An empirical study of polish listed companies. Sustainability 2017, 9, 1934. [CrossRef]

42. Shin, I.; Park, S. Role of foreign and domestic institutional investors in corporate sustainability: Focusing on R \& D investment. Sustainability 2020, 12, 8745.

43. Choi, D.; Chung, C.Y.; Kim, Y.E.; Kim, Y.J.; Choi, P.M.S. Sustainable corporate ownership structures and earnings management in the Vietnamese stock market. Sustainability 2020, 12, 6089. [CrossRef]

44. McGuinness, P.B.; Joao, P.V.; Wang, M. The role of board gender and foreign ownership in the CSR performance of Chinese listed firms. J. Corp. Financ. 2017, 42, 75-99. [CrossRef]

45. Gulzar, M.; Cherian, J.; Hwang, J.; Jiang, Y.; Sial, M. The impact of board gender diversity and foreign institutional investors on the corporate social responsibility (CSR) engagement of Chinese listed companies. Sustainability 2019, 11, 307. [CrossRef]

46. North, D. Institutions, Institutional Change and Economic Performance; Harvard University Press: Cambridge, MA, USA, 1990.

47. Pogrebnyakov, N.; Maitland, C.F. Institutional distance and the internationalization process, The case of mobile operators. J. Int. Manag. 2011, 17, 68-82. [CrossRef]

48. Huang, X.; Hu, Z.; Liu, C.; Yu, D.; Yu, L. The relationships between regulatory and customer pressure, green organizational responses, and green innovation performance. J. Clean. Prod. 2016, 112, 3423-3433. [CrossRef]

49. Ortas, E.; Gallego-Alvarez, I.; Alvarez, E.I. Financial factors influencing the quality of corporate social responsibility and environmental management disclosure: A quantile regression approach. Corp. Soc. Responsib. Environ. Manag. 2015, 22, 362-380. [CrossRef]

50. Keig, D.L.; Brouthers, L.E.; Marshall, V.B. Formal and informal corruption environments and multinational enterprise social irresponsibility. J. Manag. Stud. 2015, 52, 89-116. [CrossRef]

51. Zaheer, S. Overcoming the liability of foreignness. Acad. Manag. J. 1995, 38, 341-363.

52. Boehe, D.M. Exploiting the liability of foreign-ness, why do service firms exploit foreign affiliate networks at home? J. Int. Manag. 2011, 17, 15-29. [CrossRef]

53. Ren, B.; Zheng, Y. On the research frontier of the liability of the foreignness and its future prospect. Foreign Econ. Manag. 2012, 2, 27-34. (In Chinese)

54. Rayl, L. Why we give, testing economic and social psychological accounts of altruism. Polity 1998, 30, 383-416.

55. Veugelersr, R. Locational determinants and ranking of host countries, an empirical assessment. Kyklos 2010, 44, 363-382. [CrossRef]

56. Xiao, H. Does Institutional Distance Have Effect on Multinationals' CSR performance in Host Country? J. Quant. Tech. Econ. 2014, 4, 50-67. (In Chinese) 
57. Gaur, A.S.; Lu, J.W. Ownership Strategies and Survival of Foreign Subsidiaries, Impacts of Institutional Distance and Experience. J. Manag. 2007, 33, 84-110. [CrossRef]

58. Aleksynska, M.; Havrylchyk, O. FDI from the south, the role of institutional distance and natural resources. Eur. J. Political Econ. 2013, 29, 38-53. [CrossRef]

59. Sun, Z.; Wu, D.; Guo, S. Empirical analysis of cross-border alienation of social responsibility of multinational companies in China. Friends Account. 2017, 5, 62-66. (In Chinese)

60. Shayuti, M.A.; David, H.; Chris, J.S. The influence of culture and corporate governance on corporate social responsibility disclosure, A cross country analysis. J. Clean. Prod. 2018, 198, 820-832.

61. Ling, P.S.; Lim, M.K.; Tseng, M.L. Assessing sustainable foreign direct investment performance in Malaysia: A comparison on policy makers and investor perceptions. Sustainability 2020, 12, 8749. [CrossRef]

62. Islam, M.A.; Khan, M.A.; Popp, J.; Sroka, W.; Oláh, J. Financial development and foreign direct investment-The moderating role of quality institutions. Sustainability 2020, 12, 355. [CrossRef]

63. Oh, W.Y.; Chang, Y.K.; Martynov, A. The effect of ownership structure on corporate social responsibility: Empirical evidence from Korea. J. Bus. Ethics 2011, 104, 283-297. [CrossRef]

64. Juil, L.; Sang-Joon, K.; Insu, K. Corporate social responsibility as a strategic means to attract foreign investment: Evidence from Korea. Sustainability 2017, 9, 2121.

65. Shao, M.; Bao, Q. The impact of FDI on labor rights and interests in China: Improvement or deterioration? Manag. World 2013, 9 , 38-49. (In Chinese)

66. Tan, J. Institutional Structure and Firm Social Performance in Transitional Economies: Evidence of Multinational Corporations in China. J. Bus. Ethics 2009, 86, 171-189. [CrossRef]

67. Cheung, Y.L.; Kong, D.; Tan, W.; Wang, W. Being Good When Being International in an Emerging Economy, The Case of China. J. Bus. Ethics 2015, 130, 805-817. [CrossRef]

68. Zhou, C. The impact of foreign equity participation, institutional ownership and executive ownership on corporate social responsibility. Green Financ. Account. 2015, 10, 37-45. (In Chinese)

69. Boettke, P.J.; Coyne, C.J.; Leeson, P.T. Institutional Stickiness and the New Development Economics. Am. Econ. Sociol. 2008, 67, 331-358. [CrossRef]

70. Choi, J.; Chang, Y.K.; Li, Y.J.; Jang, M.G. Doing good in another neighborhood: Attributions of CSR motives depend on corporate nationality and cultural orientation. J. Int. Mark. 2016, 24, 82-102. [CrossRef]

71. Liang, H.; Renneboog, L. On the foundations of corporate social responsibility. J. Financ. 2016, 72, 853-909. [CrossRef]

72. Chao, M.C.; Kumar, C.V. The impact of institutional distance on the international diversity-performance relationship. J. World Bus. 2010, 45, 93-103. [CrossRef]

73. Alexander, D.; Lins, K.V.; Lukas, R.; Wagner, H.F. Do institutional investors drive corporate social responsibility? International evidence. J. Financ. Econ. 2018, 131, 693-714.

74. Zhou, Y.; Li, T.; Liu, Z. “One Belt and One Road" initiative, institutional distance and enterprise OFDI. Friends Account. 2019, 22, 80-84. (In Chinese)

75. Yi, C.; Liu, X.; Wang, Y.; Huang, J. Institutional Distance and Foreign Subsidiary Survival, the Moderating Perspective on the Enterprise Ownership and International Experience. J. Int. Trade 2019, 9, 115-132. (In Chinese)

76. Carroll, A.B. A Three-Dimensional Conceptual Model of Corporate Performance. Acad. Manag. Rev. 1979, 4, 497-505. [CrossRef]

77. Chen, Y.; Ma, L.; Zhong, C. Determinants of China's investment in Africa, An Empirical Analysis from the perspective of integrating resources and institutions. J. World Econ. 2012, 35, 91-112. (In Chinese)

78. Chen, J.; Chen, D. Opening Degree of Trade, Economic Freedom and Economic Growth, The Analysis of Based on China and Relevant Countries along “One Belt and One Road”. Wuhan Univ. J. 2017, 70, 46-57. (In Chinese)

79. Shen, J.; Dai, J. Analysis of the impact of host country institution quality on China's OFDI reverse technology spillover effect. J. Commer. Econ. 2015, 5, 91-92. (In Chinese)

80. Liu, K.; Deng, Y. Institutional environment, industry differences and location selection of FDI, Empirical Evidence from China in 2003-2012. World Econ. Stud. 2014, 10, 73-79. (In Chinese)

81. Chen, C. The Influence of Host Economic Freedom of Host Country on China's OFDI; Nanjing University: Nanjing, China, 2019. (In Chinese)

82. Lau, C.M.; Lu, Y.; Liang, Q. Corporate Social Responsibility in China, A Corporate Governance Approach. J. Bus. Ethics 2016, 136, 73-87. [CrossRef]

83. Song, L.; Bin, B.; Qiao, X. Research on the Influence of Institutional Distance on Corporate Social Responsibility of Chinese Overseas Investment Firms, Moderating Effect Based on International Experience. J. Beijing Technol. Bus. Univ. 2019, 340, 94-103. (In Chinese)

84. Liu, X.; Zhang, C. Corporate governance, social responsibility information disclosure, and enterprise value in China. J. Clean. Prod. 2017, 142, 1075-1084. [CrossRef]

85. Pengcheng, T.; Shuwang, Y.; Dirk, B. Ownership and Corporate Social Performance in China, Why geographic remoteness matters. J. Clean. Prod. 2018, 197, 1284-1295. 